\section{Private Higher Education in}

\section{Greece: Protests Against} Recognition

\section{Christopher Ziguras and Grant McBurnie}

Christopher Ziguras is senior research fellow in the Globalism Institute at the Royal Melbourne Institute of Technology. Address: GPO Box 2476V, Melbourne 3001, Australia. E-mail: christopher.ziguras@rmit.edu.au. Grant McBurnie is executive officer in Office of the Deputy Vice-Chancellor (International) at Monash University in Melbourne, Australia. Address: Monash University 3800, Australia. E-mail: grant.mcburnie@adm .monash.edu.au.

$\mathrm{I}^{\mathrm{n}}$ early June this year, some I0,000 students marched through the streets of Athens, congregating outside the Greek Parliament. They carried banners and handed out manifestos to bystanders. The situation escalated, with hard-core protesters throwing petrol bombs and rocks, smashing store windows, and setting fire to banks and cars. Police responded with tear gas and water cannon. Several more protests occurred across Greece that day and in the following weeks. Athenian students, emboldened by the success of the recent wave of protests in Paris, prefer the French term "manifestations" to describe these events.

The demonstrations are in response to mooted changes in the structure of the higher education system, the most controversial of which is the government's proposal to alter the constitution (a process taking two parliamentary terms) to allow for the establishment of "nonstate, nonprofit" universities. Since I975, the idealist position that higher education should be egalitarian and free has been enshrined in Greece's Constitution, compelling successive governments to protect a state monopoly by resisting the recognition of foreign and private higher education within its borders. Enrollments in the public higher education system, comprising universities and technological education institutes, has been expanded dramatically over the past decade; but funding per student remains very low, leading to severe overcrowding and little opportunity for students to interact meaningfully with faculty.

\section{The "Extralegal" Private Sector}

Despite the constitutional prohibition, around 40 private tertiary colleges now exist in Greece, together enrolling around 35,000 students with tuition fees averaging 4,500 euros. Between them they offer over 200 programs, mostly through partnerships with foreign universities, more than half of which are from the United Kingdom, a quarter from France, and some I5 percent from the United States. This is made possible by a I935 law allowing private companies offering postsec- ondary school education to exist under the name of Laboratories of Liberal Studies. Like other companies, they are registered as businesses with the Ministry of Commerce. However, they are not recognized as educational institutions by the state and so are not subject to any regulation by educational authorities. Due to the regulatory vacuum, they vary considerably in size, quality, facilities, and professionalism.

Qualifications gained through study at these colleges are not recognized by the Greek government or Greek public education institutions. As a result, students in transnational programs in Greece are not able to apply for graduate-level employment in the public sector, defer military service, obtain professional registration, or undertake subsequent studies at Greek universities. Over the past decade, Greece has repeatedly been taken to the European Court of Justice over complaints by the European Commission that the refusal to recognize EU member-country qualifications obtained through transnational programs is in breach of EU Directives 89/48 and 05/36, which facilitate professional mobility within the union.

Following the demonstrations, an opinion poll commissioned by the Kathimerini newspaper (June 30, 2006) found that 59 percent of respondents favored the recognition of private universities and only 25 percent were satisfied with the current operation of Greek public universities. Critics of Greek educational protectionism argue that it has resulted in an undersupply of student places, degradation of the quality of education due to lack of competition, and the world's highest per capita student exodus abroad. Graduate unemployment has also risen as graduates of local institutions carry supplydriven qualifications less popular with industry, while gradu-

Since 1975, the idealist position that higher education should be egalitarian and free has been enshrined in Greece's Constitution

ates of foreign institutions face nonrecognition or delays in recognition of their qualifications.

Unmet demand for tertiary education has long been a highprofile political issue in Greece, with the annual national examinations and competition for places attracting much press coverage. Parents of secondary school students routinely pay hefty fees to after-hours cramming schools to increase their offspring's chances of gaining entry into prestigious public universities. The Athens News, for example, recently noted that "over 40 percent of university candidates failed to reach the minimum score . . . so they will be barred from the Greek dream" (June 30, 2006).

\section{ANTI-IMPERIALISM AND EMPLOYABILITY}

The student movement's opposition to new private providers arose from both ideological and practical bases. Many of the 
protesters see themselves as being on the frontline in the battle against "corporate" globalization. They are fighting to protect the integrity of the Greek state and to maintain its strong control of the education system and the economy as a whole, in the face of what many describe as "Anglo-Saxonic imperialism." Greece has long had a highly regulated economy; and the widespread suspicion of markets fuels broad sympathy, if not support, for the student movement.Even the youth wing of the conservative New Democracy does not support allowing forprofit institutions to operate in the higher education sector.

The students' opposition to private providers also stems from a more practical concern about their job prospects upon graduation. The Athenian newspaper Kathimerini recently editorialized that student reactions can be largely attributed to anxiety about their likely postuniversity unemployment (or underemployment) and concluded that "their rage is directed against the broader political system, which has in past decades set up a largely useless industry churning out degrees with no practical value" (June IO-II, 2006). Sadly, most student and academic groups are hostile toward any suggestion that higher education qualifications should be made more relevant to the labor market. Instead, most of those inside the state university system are set on ensuring that jobs in the public sector and regulated professions will not be open to the more readily employable graduates of private institutions with better facilities, internationalized curricula, and much shorter degrees. The Greek labor market is highly regulated, which effectively protects those in the workforce against competition from those outside it, resulting in a high rate of youth and graduate unemployment. The student movement offers the same logic in seeking to maintain the state's preferential treatment of those who have managed to gain admission to the public universities in the face of competition from those who have not.

The students' opposition to private providers also stems from a more practical concern about their job prospects upon graduation.

\section{More Tear Gas to Come}

Both major political parties favor constitutional reform, regarding it as one of many steps that will in the long run benefit the Greek economy while bringing it into line with practice in much of the EU. The changes are therefore likely to happen, but will take several years, much dialogue with stakeholders, and work to establish appropriate regulatory systems. The amendments would open the way for local private colleges to seek university status and for foreign universities to establish recognized branch campuses in Greece. This could have several benefits for the country, including helping to address unmet demand in certain disciplines, promoting professional mobili- ty for more of its citizens, and allowing for the establishment (long overdue) of accreditation and quality assurance systems for private providers. Public universities and their student movements will most likely maintain their strident opposition to the private sector and, if the amendment passes, will seek to ensure that the state enforces the same debilitating conditions on the new private institutions as it imposes on the public system. The question on everybody's lips is whether the current government considers university reform important enough to fight for. The time frame required to amend the Constitution and implement a new regulatory framework for private institutions promises to create a decade of skirmishes on the streets of Athens.

\section{Higher Education and Poverty in Sub-Saharan Africa David E. Bloom, David Canning, and Kevin Chan}

David E. Bloom is professor of economics and demography at the Harvard School of Public Health. Address: HSPH, $66_{5}$ Huntington Ave., Boston, MA 02115, USA. E-mail: dbloom@hsph.harvard.edu. David Canning is professor of economics and international health at the Harvard School of Public Health. E-mail: dcanning@hsph.harvard.edu. Kevin Chan is a doctoral student in the Department of Population and International Health at the Harvard School of Public Health. E-mail: kchan@hsph.harvard.edu.

For several decades, donor institutions have placed great $\boldsymbol{F}$ emphasis on primary and, more recently, secondary education in their development assistance to sub-Saharan Africa. But they have neglected tertiary education as an added means to improve economic growth and mitigate poverty. There is a persistent belief in the international development community that tertiary education has little role in promoting poverty alleviation. New evidence suggests that this belief may be misguided and that tertiary education may play a significant role in enhancing economic growth and poverty reduction.

\section{Higher Education in Africa}

By decreasing its funding of higher education, the international development community has encouraged African governments' relative neglect of higher education. From 1985 to I989, I7 percent of the World Bank's worldwide education-sector investment financing focused on higher education. But from I995 to I999, the proportion allotted to higher education declined to just 7 percent. Higher education in Africa has suffered from such reductions. Many African countries struggle to maintain even low enrollment levels; sub-Saharan Africa's 